\title{
Respiratory symptoms, lung function, and sensitisation to flour in a British bakery
}

\author{
A W MUSK, ${ }^{1 *} \mathrm{~K}$ M VENABLES, ${ }^{1}$ B CROOK,${ }^{2} \dagger$ A J NUNN ${ }^{3}$ R HAWKINS, ${ }^{1}$ \\ G D W CROOK, ${ }^{1}$ B J GRANEEK, ${ }^{2}$ R D TEE, ' N FARRER, ' D A JOHNSON, \\ D J GORDON, ' J H DARBYSHIRE, ${ }^{3}$ A J NEWMAN TAYLOR'
}

From the Department of Occupational Medicine, ${ }^{1}$ National Heart and Lung Institute, Brompton Hospital, London SW3 6HP, AFRC Institute of Arable Crops Research, ${ }^{2}$ Rothamsted Experimental Station, Harpenden, Herts, and MRC Cardiothoracic Epidemiology Group, ${ }^{3}$ Brompton Hospital, London SW3 6HP, UK

ABSTRACT A survey of dust exposure, respiratory symptoms, lung function, and response to skim prick tests was conducted in a modern British bakery. Of the 318 bakery employees, $279(88 \%)$ toole part. Jobs were ranked from 0 to 10 by perceived dustiness and this ranking correlated well with tota\$ dust concentration measured in 79 personal dust samples. Nine samples had concentrations greatep than $10 \mathrm{mg} / \mathrm{m}^{3}$, the exposure limit for nuisance dust. All participants completed a self administeree questionnaire on symptoms and their relation to work. FEV 1 and FVC were measured by a dry wedge spirometer and bronchial reactivity to methacholine was estimated. Skin prick tests were performe with three common allergens and with 11 allergens likely to be found in bakery dust, including mite $\$$ and moulds. Of the participants in the main exposure group, $35 \%$ reported chest symptoms which in $13 \%$ were work related. The corresponding figures for nasal symptoms were $38 \%$ and $19 \%$ 은 Symptoms, lung function, bronchial reactivity, and response to skin prick tests were related to current or past exposure to dust using logistic or linear regression analysis as appropriate. Exposure rank significantly associated with most of the response variables studied. The study shows that respiratory symptoms and sensitisation are common, even in a modern bakery.

Occupational asthma and rhinitis occur in bakers ${ }^{1}$ and the environmental agents responsible appear to be components of the grain itself $\mathrm{f}^{-4}$ or grain contaminants, such as mites, weevils, and moulds ${ }^{5-7}$ The relative importance of these potential allergens may vary according to the source of the flour, conditions of storage, and intensity of exposure. Recent papers describing grain components as important allergens have come from Australia, ${ }^{2-4}$ where grain has a low moisture content. A higher moisture content, or storage of grain or flour for long periods, may promote the growth of contaminant micro-organisms, mites, and insects. Materials added to flour before baking, such as yeast and amylase, derived from Aspergillus species, ${ }^{8}$ may also be allergenic.

*Present address: Sir Charles Gairdner Hospital, Nedlands, Western Australia.

†Present address: Occupational Medicine and Hygiene Laboratories Health and Safety Executive, London NW2 6LN.

Accepted 24 October 1988
As many as a third of bakers and grain workers ma: show evidence of sensitisation, ${ }^{9-11}$ which appears to be related to intensity and duration of exposure in the $\overrightarrow{\vec{E}}$ industry as well as to host factors, such as atopy. ${ }^{11}$ Mechanisms involving IgE and the mast cell have bee implicated, ${ }^{12} 13$ but precipitins to components of flou? have also been identified ${ }^{5}$ and non-immunologica processes, such as direct activation of complemeng pathways, may be involved. ${ }^{14}$

Apart from case reports, there is little information. about asthma and sensitisation in British bakers. This study was designed to $(a)$ describe the levels of exposure to bakery dust in a modern British bakeryo (b) estimate the prevalence of symptoms and sensitisas tion in the workforce of the bakery, and (c) explore relations between indices of exposure and response.

\section{Methods}

STUDY DESIGN AND SUBJECTS

The study was a cross sectional survey of current employees conducted over six consecutive days an nights. All current workers with the exception o\$ 
drivers and salesmen, whose contact with the bakery involved only the collection of goods for delivery, were invited to participate in the study.

\section{DETERMINATION OF CURRENT EXPOSURE CONCENTRATIONS}

Concentrations of airborne dust in the breathing zones of workers were determined with personal air samplers. Either open faced filter holders (Casella, London) housing preweighed $25 \mathrm{~mm}$ diameter glass microfibre filters (GF/A, Whatman, Maidstone; nominal pore size $1.6 \mu \mathrm{m}$ ), or closed face $37 \mathrm{~mm}$ diameter three piece polystyrene aerosol monitors (Millipore, Harrow) housing preweighed $0.8 \mu \mathrm{m}$ pore size polycarbonate membrane filters (Nuclepore; Sterilin; Hounslow) were used. These were connected to portable, battery operated vacuum pumps (AFC123, Casella or L2SF, Rotheroe and Mitchell, Aylesbury) sampling at air flow rates of $21 / \mathrm{min}$.

The bakery was divided into five main structurally separate areas: the main bread bakery; the confectionery bakery for producing buns, rolls, scones, and pastries; the hot plate bakery for producing pancakes and crumpets; the workshop area; and the administration offices and canteen. Within each area one or more employees wore sampling devices for periods of up to eight hours to provide gravimetric measurements of total airbone dust.

\section{EXPOSURE RANKING}

Independently of the measurement of dust concentrations, each employment category was ranked on a scale of 0 to 10 for perceived dustiness by the bakery manager in consultation with an occupational physician from the baking industry (table 1). Office; transport, and workshop staff who worked in physically separate accommodation and never entered production areas were graded 0 , whereas subjects working in the flour room or in the manufacture of scones were graded 10.

\section{WORK PLA CE EXPOSURE MEASUREMENTS}

Seventy nine personal dust samples were collected throughout the bakery (table 1). Nine of the samples had concentrations in excess of the exposure limit for nuisance dust $\left(10 \mathrm{mg} / \mathrm{m}^{3}\right){ }^{15}$ The geometric mean total dust concentrations were, in general, consistent with the rank of workplace exposure (table 1) but there was considerable variation within some exposure ranks, such as exposure rank 6 .

\section{RESPIRATORY QUESTIONNAIRE}

All participants completed a self administered questionnaire on respiratory symptoms based on the Medical Research Council (MRC) Questionnaire (1976). Additional questions were added to indicate whether the respiratory symptoms experienced (breathlessness, wheeze, chest tightness, and sneezing or itchy, running nose) improved on days off work or on holidays (if they did they were considered to be work related). Further questions asked if the participant thought that work "affected" his or her chest or nose. Participants also completed questions on smoking habits and on occupational history. Smokers were defined as those who had smoked at least one cigarette a day or equivalent in other tobacco products for at least one year and ex-smokers had ceased smoking at least six months before the study.

Chronic bronchitis was defined as sputum production on most days for at least three months each year.

Table 1 Number of employees participating in the study and results of dust sampling by exposure rank

\begin{tabular}{|c|c|c|c|c|c|c|c|}
\hline \multirow[b]{2}{*}{ Rank } & \multirow[b]{2}{*}{ Employment } & \multirow{2}{*}{$\begin{array}{l}\text { Total No } \\
\text { of } \\
\text { employees }\end{array}$} & \multicolumn{2}{|c|}{ Participants } & \multirow{2}{*}{$\begin{array}{l}\text { No of } \\
\text { samples } \\
\text { tested }\end{array}$} & \multicolumn{2}{|c|}{$\begin{array}{l}\text { Dust sampling total dust } \\
\left(\mathrm{mg} / \mathrm{m}^{3}\right)\end{array}$} \\
\hline & & & No & $\%$ & & Range & $\begin{array}{l}\text { Geometric } \\
\text { mean }\end{array}$ \\
\hline $\begin{array}{l}0 \\
1\end{array}$ & $\begin{array}{l}\text { Office, transport, and vehicle-workshop staff } \\
\text { Despatch, traywashing, nursing, and canteen } \\
\text { staff }\end{array}$ & 52 & 37 & 71 & 1 & $0 \cdot 18$ & $0 \cdot 18$ \\
\hline $\begin{array}{l}2 \\
2 \\
3 \\
4 \\
5 \\
6 \\
7\end{array}$ & $\begin{array}{l}\text { Despatch, traywasning, nursing, and canteen } \\
\text { staff } \\
\text { Slicers, wrappers, and packers } \\
\text { Bakery manager, quality control staff } \\
\text { Production foremen, security staff } \\
\text { Bakery maintenance staff } \\
\text { Staff attending ovens or in cooking areas } \\
\text { Bakery cleaning staff, doughmakers (main }\end{array}$ & $\begin{array}{r}23 \\
84 \\
7 \\
29 \\
20 \\
29\end{array}$ & $\begin{array}{r}23 \\
70 \\
6 \\
28 \\
19 \\
26\end{array}$ & $\begin{array}{c}(100) \\
83 \\
(86) \\
97 \\
(95) \\
90\end{array}$ & $\begin{array}{r}2 \\
23 \\
0 \\
5 \\
1 \\
16\end{array}$ & $\begin{array}{l}0.00-0.08 \\
0.00-3.65 \\
\overline{0.01}-0.99 \\
2.97 \\
0.00-37.57\end{array}$ & $\begin{array}{l}0.01 \\
0.34 \\
0.24 \\
2.97 \\
1.73\end{array}$ \\
\hline 8 & $\begin{array}{l}\text { Bakery cleaning stan, dougnmakers (main } \\
\text { bread bakery) }\end{array}$ & 57 & 54 & 95 & $12[2]$ & $0.01-16.80$ & $2 \cdot 13$ \\
\hline 9 & $\begin{array}{l}\text { (hot plate bakery) } \\
\text { Staff preparing ingredients in confectionery }\end{array}$ & 9 & 9- & & $10[1]$ & $0 \cdot 59-14 \cdot 10$ & $2 \cdot 69$ \\
\hline 10 & $\begin{array}{l}\text { bakery } \\
\text { Flour room staff, scone production staff }\end{array}$ & $\begin{array}{l}2 \\
6\end{array}$ & $\begin{array}{l}2 \\
5-\end{array}$ & (94) & $2[1]$ & $\begin{array}{l}9.97-12.05 \\
1.84-13.03\end{array}$ & $\begin{array}{r}11.00 \\
6.59\end{array}$ \\
\hline & Total & 318 & 279 & 88 & 79 [9] & - & - \\
\hline
\end{tabular}

Percentages in round parentheses are based on fewer than 25 subjects. Numbers in square parentheses refer to samples with levels above $10 \mathrm{mg} / \mathrm{m}^{3}$ (the exposure limit for nuisance dust is $10 \mathrm{mg} / \mathrm{m}^{3}$ ). 
Dyspnoea was defined as being troubled by shortness of breath when hurrying on level ground or walking up a slight hill.

\section{PULMONARY FUNCTION}

Forced expiratory volume in one second $\left(\mathrm{FEV}_{1}\right)$ and forced vital capacity (FVC) were measured with one of four dry wedge spirometers (Vitalograph, Buckingham). These were checked for leakages and calibration (using a one litre syringe) at least three times each day. Measurements were expressed at ATPS and a calibration factor for each spirometer was included. The best FEV 1 and the best FVC was taken from three technically satisfactory forced expiratory manoeuvres where the best two recordings were within $5 \%$ of each other. ${ }^{16}$ All measurements were made at an ambient temperature within the range $18-23^{\circ} \mathrm{C}$.

Each individual's FEV 1 and FVC was divided by the square of height and standardised to age 25 years using age regression coefficients calculated from the study participants. Separate linear regressions were used for subjects over or under 25 .

\section{NON-SPECIFIC BRONCHIAL REACTIVITY}

Non-specific bronchial reactivity was measured by the method of Yan et al ${ }^{17}$ using hand held De Vilbiss No 40 nebulisers to a total cumulative dose of methacholine of $120 \mathrm{mcmol}$. The provocative cumulative dose of methacholine producing a $20 \%$ fall relative to the postsaline $F E V_{1}\left(\mathbf{P D}_{20}\right)$ was calculated by linear interpolation of the final two points on a logarithmic scale.

\section{SKIN PRICK TESTS}

Skin prick tests were performed on the flexor surface of the forearm using the following allergen extracts: B2 grass pollen (4100, Bencard), Dermatophagoides pteronyssinus (2801, Bencard), cat fur (3204, Bencard), wheat grain (5101, Bencard), Aspergillus fumigatus (2000, Bencard) bakers yeast (7902, Bencard), mould mix (Alternaria alternata, A fumigatus, Cladosporium herbarum, Penicillium notatum, Dome/Hollister Stier), Tribolium confusum $(5 \mathrm{mg} / \mathrm{ml}$, Health and Safety Executive, London), mixed flour (5105, Bencard), Tyrophagus longior $(5 \mathrm{mg} / \mathrm{ml}$, Health and Safety Executive, London), Acarus siro $(5 \mathrm{mg} / \mathrm{ml}$, Health and Safety Executive, London), Glycyphagus destructor (5 $\mathrm{mg} / \mathrm{ml}$, Health and Safety Executive, London), Tyrophagus putrescentiae $(5 \mathrm{mg} / \mathrm{ml}, 78 / 517$ National Institute of Biological Standards and Control), and $G$ domesticus $(5 \mathrm{mg} / \mathrm{ml}$, Brompton Hospital). Positive control was histamine dihydrogen chloride and negative control was Coca's solution. All tests were read at 10 minutes. The mean of the greatest dimension of the weal and the dimension at right angles to this was calculated. A mean weal diameter of $2 \mathrm{~mm}$ or more greater than the negative control was considere $\bar{\phi}$ positive. Subjects were classified as atopic if they has one of more positive responses to common allergen 8 (grass pollen, $D$ pteronyssinus, or cat fur). They were: considered "grain mite positive" if they had a positive response to $T$ longior, $A$ siro, $G$ destructor, $T$ putrescen $-\overrightarrow{0}$ tiae, or $G$ domesticus. Additionally, if $T$ confusum baker's yeast, mixed flour, wheat grain, mould mix, fumigatus, or any of the grain mites were positive subjects were classified as "bakery antigen positive." STATISTICAL PROCEDURES

The statistical significance of the relation of potentia $\vec{P}$ explanatory variables to symptoms, bronchial reactivity, and skin response was examined by using logistic regression analysis; the relation to $\mathrm{FEV}_{1} / \mathrm{FV} \mathcal{Q}$ ratio was analysed using linear regression. ${ }^{18}$ The independent explanatory variables included in the analyses were age, sex, current smoker, ever smokedo atopic status, years worked in the bakery, curren exposure rank, whether currently working at exposure rank 6 or more, and whether ever worked at exposurs rank 6 or more.

\section{Results}

CHARACTERISTICS OF THE SUBJECTS

A total of $279(88 \%)$ of the 318 bakery employees took part in the survey (table 1), $92 \%$ of the men an $\$$ $82 \%$ of the women. Two men and three women werie unavailable because of illness and two men and gne woman were on holiday. Twelve men and 19 worme refused to take part in the study. Of the 39 worker who did not take part, 15 were from rank 0 (with this lowest exposure), six from rank 2 , and one from ran 3. In all other exposure categories at least $90 \%$ of work force took part.

Twenty six male workers (a subset of exposure rank 7) were employed only on Saturdays to clean the bakery during its non-production day. They weré much younger than the other workers (all were 20 of under compared with the remainder of the male work force of whom $77 \%$ were 25 or more) and all but two had been employed for less than two years. In additio 19 male maintenance workers (all those in exposure rank 5) had intermittent exposure. These two groups were therefore considered separately from the maio group and are referred to as the intermittent exposures group in all subsequent analyses. The multivariate. analyses identified a history of exposure rank 6 on more (past or present) to be the measure of exposure most frequently associated with response variables Therefore the results in tables $2-4$ are presented according to this categorisation of exposure.

In all, $55 \%$ of the workers in the main group were men (table 2) but the proportion varied in the differento exposure categories. About half the workers had been $n^{+}$ 
Table 2 Characteristics of study population by exposure rank. (Percentages in parentheses are based on fewer than 25 subjects)

\begin{tabular}{|c|c|c|c|c|c|c|}
\hline & \multicolumn{6}{|c|}{ Percentage in given exposure rank } \\
\hline & \multicolumn{4}{|c|}{ Main group } & \multicolumn{2}{|c|}{$\begin{array}{l}\text { Intermittent } \\
\text { exposure } \\
\text { group }\end{array}$} \\
\hline & $\begin{array}{l}\text { Never } \\
\geqslant 6\end{array}$ & $\begin{array}{l}\text { Past } \\
\geqslant 6 \text { only }\end{array}$ & $\begin{array}{l}\text { Current } \\
\geqslant 6\end{array}$ & Total & 5 & $7 *$ \\
\hline $\begin{array}{l}\text { Sex: Male } \\
\text { Age (y): } \begin{aligned}<25 \\
25-44 \\
\geqslant 45\end{aligned}\end{array}$ & $\begin{array}{l}39 \\
24 \\
36 \\
40\end{array}$ & $\begin{array}{l}72 \\
13 \\
56 \\
31\end{array}$ & $\begin{array}{l}73 \\
34 \\
31 \\
34\end{array}$ & $\begin{array}{l}55 \\
25 \\
38 \\
37\end{array}$ & $\begin{array}{r}(100) \\
(16) \\
(53) \\
(32)\end{array}$ & $\begin{array}{r}100 \\
100 \\
0 \\
0\end{array}$ \\
\hline $\begin{array}{l}\text { Years employed in } \\
<2 \\
2-10 \\
>10\end{array}$ & $\begin{array}{l}\text { bakery: } \\
28 \\
47 \\
25\end{array}$ & $\begin{array}{r}0 \\
59 \\
41\end{array}$ & $\begin{array}{l}23 \\
56 \\
21\end{array}$ & $\begin{array}{l}22 \\
52 \\
26\end{array}$ & $\begin{array}{l}(5) \\
(63) \\
(32)\end{array}$ & $\begin{array}{r}92 \\
8 \\
0\end{array}$ \\
\hline $\begin{array}{l}\text { Smoking status: } \\
\text { Current smoker } \\
\text { Ex-smoker } \\
\text { Never smoked }\end{array}$ & $\begin{array}{l}47 \\
17 \\
36\end{array}$ & $\begin{array}{l}59 \\
26 \\
15\end{array}$ & $\begin{array}{l}54 \\
11 \\
34\end{array}$ & $\begin{array}{l}51 \\
17 \\
32\end{array}$ & $\begin{array}{l}(63) \\
(21) \\
(16)\end{array}$ & $\begin{array}{r}23 \\
0 \\
77\end{array}$ \\
\hline Atopic & 41 & 38 & 30 & 37 & $(50)$ & 62 \\
\hline Total assessed & 125 & 39 & 234 & 19 & 26 & \\
\hline
\end{tabular}

*A subset of exposure rank 7 .

Table 3 Symptoms reported by exposure rank. (Percentages in parentheses are based on fewer than 25 subjects)

\begin{tabular}{|c|c|c|c|c|c|c|}
\hline \multirow[b]{4}{*}{ Symptoms } & \multicolumn{6}{|c|}{ Percentage in exposure rank } \\
\hline & \multicolumn{4}{|c|}{ Main group } & \multirow{2}{*}{\multicolumn{2}{|c|}{$\begin{array}{l}\text { Intermittent } \\
\text { exposure } \\
\text { group }\end{array}$}} \\
\hline & \multirow{2}{*}{$\begin{array}{l}\text { Never } \\
\geqslant 6\end{array}$} & \multirow{2}{*}{$\begin{array}{l}\text { Past } \\
\geqslant 6 \text { only }\end{array}$} & \multirow{2}{*}{$\begin{array}{l}\text { Current } \\
\geqslant 6\end{array}$} & \multirow[b]{2}{*}{ Total } & & \\
\hline & & & & & 5 & $7^{*}$ \\
\hline $\begin{array}{l}\text { Chronic bronchitis } \\
\text { Dyspnoea } \\
\text { Wheeze: }\end{array}$ & $\begin{array}{r}6 \\
17\end{array}$ & $\begin{array}{l}23 \\
28\end{array}$ & $\begin{array}{l}21 \\
19\end{array}$ & $\begin{array}{l}13 \\
19\end{array}$ & $\begin{array}{l}(5) \\
(0)\end{array}$ & $\begin{array}{l}0 \\
8\end{array}$ \\
\hline $\begin{array}{l}\text { Any } \\
\text { Work related }\end{array}$ & $\begin{array}{r}19 \\
6\end{array}$ & $\begin{array}{l}36 \\
10\end{array}$ & $\begin{array}{l}26 \\
13\end{array}$ & $\begin{array}{r}24 \\
9\end{array}$ & $\begin{array}{r}(21) \\
(5)\end{array}$ & $\begin{array}{r}23 \\
0\end{array}$ \\
\hline Chest tightness: & & & & & & \\
\hline $\begin{array}{l}\text { Any } \\
\text { Work related }\end{array}$ & $\begin{array}{r}14 \\
5\end{array}$ & $\begin{array}{r}33 \\
8\end{array}$ & $\begin{array}{r}21 \\
7\end{array}$ & $\begin{array}{r}20 \\
7\end{array}$ & $\begin{array}{r}\text { (16) } \\
(5)\end{array}$ & $\begin{array}{l}8 \\
0\end{array}$ \\
\hline Difficulty in breathi & ing: & & & & & \\
\hline $\begin{array}{l}\text { Any } \\
\text { Work related }\end{array}$ & $\begin{array}{r}12 \\
4\end{array}$ & $\begin{array}{r}23 \\
8\end{array}$ & $\begin{array}{r}17 \\
9\end{array}$ & $\begin{array}{r}16 \\
6\end{array}$ & $\begin{array}{r}(12) \\
(0)\end{array}$ & $\begin{array}{l}8 \\
0\end{array}$ \\
\hline Any chest symptom & & & & & & \\
\hline $\begin{array}{l}\text { Any } \\
\text { Work related }\end{array}$ & $\begin{array}{r}31 \\
9\end{array}$ & $\begin{array}{r}51 \\
6\end{array}$ & $\begin{array}{l}35 \\
17\end{array}$ & $\begin{array}{l}35 \\
13\end{array}$ & $\begin{array}{l}(28) \\
(11)\end{array}$ & $\begin{array}{r}23 \\
0\end{array}$ \\
\hline Nasal symptoms: & & & & & & \\
\hline Any & 27 & 46 & 54 & 38 & (32) & 46 \\
\hline $\begin{array}{l}\text { Work related } \\
\text { Any chest or nasal s }\end{array}$ & $\begin{array}{c}13 \\
\text { sympto }\end{array}$ & $\begin{array}{l}20 \\
\mathrm{~ms}:\end{array}$ & 30 & 19 & (21) & 8 \\
\hline $\begin{array}{l}\text { Any } \\
\text { Work related }\end{array}$ & $\begin{array}{l}46 \\
17\end{array}$ & $\begin{array}{l}72 \\
33\end{array}$ & $\begin{array}{l}57 \\
36\end{array}$ & $\begin{array}{l}54 \\
25\end{array}$ & $\begin{array}{l}(37) \\
(26)\end{array}$ & $\begin{array}{r}62 \\
8\end{array}$ \\
\hline $\begin{array}{c}\text { chest" } \\
\text { "Work affects }\end{array}$ & 2 & 18 & 15 & 8 & (0) & 6 \\
\hline $\begin{array}{c}\text { nose" } \\
\text { "Work affects }\end{array}$ & 7 & 27 & 30 & 17 & (11) & 12 \\
\hline chest or nose" & 8 & 40 & 32 & 21 & (11) & 12 \\
\hline Total assessed & 125 & 39 & 70 & 234 & 19 & 26 \\
\hline
\end{tabular}

Symptoms are defined in the text.

*A subset of exposure rank 7 .
Table 4 Standardised $F E V_{1} / F V C$ ratio, $P D_{20}$, and results of skin prick test to any bakery antigen by exposure rank. (Percentages in parentheses are based on fewer than 25 subjects)

\begin{tabular}{|c|c|c|c|c|c|c|}
\hline & \multicolumn{6}{|c|}{ Percentage in exposure rank } \\
\hline & \multicolumn{4}{|c|}{ Main group } & \multicolumn{2}{|c|}{$\begin{array}{l}\text { Intermittent } \\
\text { exposure } \\
\text { group }\end{array}$} \\
\hline & $\begin{array}{l}\text { Never } \\
\geqslant 6\end{array}$ & $\begin{array}{l}\text { Past } \\
\geqslant 6 \text { only }\end{array}$ & $\begin{array}{l}\text { Current } \\
\geqslant 6\end{array}$ & Total & 5 & $7 *$ \\
\hline $\begin{array}{l}\text { Standardised (FE } \\
<70 \\
70- \\
80- \\
90- \\
\text { Total assessed }\end{array}$ & $\begin{array}{c}\text { (FVC) } \\
6 \\
28 \\
58 \\
8 \\
108\end{array}$ & $\begin{array}{l}\times 100: \\
11 \\
42 \\
42 \\
6 \\
36\end{array}$ & $\begin{array}{r}14 \\
39 \\
42 \\
5 \\
57\end{array}$ & $\begin{array}{r}9 \\
33 \\
51 \\
7 \\
201\end{array}$ & $\begin{array}{c}(19) \\
(38) \\
(44) \\
(0) \\
16\end{array}$ & $\begin{array}{r}5 \\
32 \\
50 \\
14 \\
22\end{array}$ \\
\hline $\begin{array}{l}\mathrm{PD}_{20}(\mathrm{mcmol}) \\
>120 \\
30-120 \\
<30 \\
\text { Total assessed }\end{array}$ & $\begin{array}{r}74 \\
15 \\
11 \\
113\end{array}$ & $\begin{array}{l}64 \\
11 \\
25 \\
36\end{array}$ & $\begin{array}{l}58 \\
24 \\
19 \\
59\end{array}$ & $\begin{array}{r}68 \\
17 \\
15 \\
208\end{array}$ & $\begin{array}{r}(53) \\
(6) \\
(41) \\
17\end{array}$ & $\begin{array}{r}71 \\
29 \\
0 \\
24\end{array}$ \\
\hline $\begin{array}{l}\text { Skin prick test } \\
\text { positive, any } \\
\text { bakery antigen }\end{array}$ & 28 & 54 & 35 & 35 & $(50)$ & 58 \\
\hline Total assessed & 118 & 39 & 60 & 217 & 18 & 24 \\
\hline
\end{tabular}

*A subset of exposure rank 7 .

employed in the bakery for between two and 10 years and further $26 \%$ for more than 10 years. About one third of the workers in the main group had never smoked, $42 \%$ of the women and $23 \%$ of the men. By contrast, $77 \%$ of the Saturday part time workers had never smoked.

\section{RESPIRATORY SYMPTOMS}

For each of the exposure ranks within the main group the prevalence of most symptoms was similar for men and women, therefore the results for both sexes have been tabulated together (table 3). Chronic bronchitis was reported by $13 \%$ of the main group, the proportion increased with increasing exposure category. Dyspnoea was more common among women $(25 \%)$ than among men (14\%) and was not associated with increasing exposure.

Thirty five per cent of the workers in the main group reported one or more chest symptoms (wheeze, chest tightness, or difficulty in breathing), $13 \%$ had work related symptoms-that is, their symptoms were better when they were away from work-and $8 \%$ considered that working in the bakery affected their chest. Nasal symptoms (sneezing or an itchy or runny nose) were common; they were reported by $38 \%$ of the main group and about half were work related. In all, $25 \%$ of those in the main group reported work related chest or nasal symptoms, the proportion being highest among those currently $(36 \%)$ or previously $(33 \%)$ in exposure rank 6 or above.

Of those in the intermittent exposure group, the 


\begin{tabular}{|c|c|c|c|c|c|}
\hline Dependent variable & $\begin{array}{l}\text { Significant } \\
\text { independent variable }(s)\end{array}$ & $\begin{array}{l}\text { Regression } \\
\text { coefficient } \\
(S E)\end{array}$ & $\begin{array}{l}\text { Constant } \\
\text { term } \\
(S E)\end{array}$ & Change & $\begin{array}{l}\text { Increas } \\
\text { in odds } \\
\text { ratio }\end{array}$ \\
\hline Chronic bronchitis & Ever $\geqslant 6$ exposure & $1.66(0.48)$ & $-2.92(0.42)$ & Ever $v$ never $\geqslant 6$ exposure & $4 \cdot 1$ \\
\hline Dyspnoea & $\begin{array}{l}\text { Female sex } \dagger \\
\text { Ever smoked }\end{array}$ & $\begin{array}{l}1.03(0.37) \\
1.08(0.44)\end{array}$ & $-3.78(0.76)$ & $\begin{array}{l}\text { Female } v \text { male } \\
\text { Ever } v \text { never smoked }\end{array}$ & $\begin{array}{l}2 \cdot 8 \\
2 \cdot 9\end{array}$ \\
\hline Work related chest symptoms & Current exposure rank & $0.14(0.07)$ & $-2 \cdot 38(0.35)$ & Increase of one exposure rank & $1 \cdot 2$ \\
\hline Work related nasal symptoms & $\begin{array}{l}\text { Current exposure rank } \\
\text { Age }\end{array}$ & $\begin{array}{r}0.25(0.06) \\
-0.04(0.01)\end{array}$ & $-1.01(0.57)$ & $\begin{array}{l}\text { Increase of one exposure rank } \\
\text { Increase of } 10 \text { years }\end{array}$ & $\begin{array}{l}1 \cdot 3 \\
0.7\end{array}$ \\
\hline $\begin{array}{l}\text { Work related chest or nasal } \\
\text { symptoms }\end{array}$ & Current exposure rank & $0.22(0.06)$ & $-1.79(0.06)$ & Increase of one exposure rank & $1 \cdot 2$ \\
\hline $\mathrm{PD}_{20}<30 \mathrm{mcmol}$ & Ever $\geqslant 6$ exposure & $0.84(0.40)$ & $-2 \cdot 13(0.30)$ & Ever $v$ never $\geqslant 6$ exposure & $2 \cdot 3$ \\
\hline $\begin{array}{l}\text { Positive skin test to one or } \\
\text { more bakery antigens }\end{array}$ & $\begin{array}{l}\text { Atopic } \\
\text { Ever } \geqslant 6 \text { exposure } \\
\text { Years worked in bakery }\end{array}$ & $\begin{array}{l}2.79(0.39) \\
1.10(0.38) \\
0.06(0.022)\end{array}$ & $-2.89(0.42)$ & $\begin{array}{l}\text { Atopic } v \text { non-atopic } \\
\text { Ever } v \text { never } \geqslant 6 \text { exposure } \\
\text { Additional } 10 \text { years in the bakery }\end{array}$ & $\begin{array}{r}16 \cdot 3 \\
3 \cdot 0 \\
1 \cdot 8\end{array}$ \\
\hline
\end{tabular}

* Based on workers in the main exposure group.

+ Male $=1$, female $=2$.

proportion reporting symptoms was generally lower than for those in the main group. This was particularly true for the subset of exposure group 7 (the Saturday cleaning workers), none of whom had chronic bronchitis or work related chest symptoms, although $23 \%$ had wheeze which was not work related. Nevertheless, $12 \%$ considered that work affected their nose or chest.

The stepwise multiple logistic regression analysis identified a measure of exposure as the most significant independent factor associated with symptoms with the exception of dyspnoea which was most common in women and was also associated with a history of smoking (table 5).

\section{PULMONARY FUNCTION TESTS}

The regression coefficients for FEV $_{\text {, against age for }}$ men and women aged 25 or more combined were approximately $0.03 \mathrm{l} /$ year both for smokers and nonsmokers. The standardised $\mathrm{FEV}_{\text {, }}$ for men was not related to any measure of exposure whereas women who had worked at some time in exposure rank 6 or more had significantly lower FEV, than those who had not.

The standardised $\mathrm{FEV}_{\mathrm{1}} / \mathrm{FVC}$ ratio tended to decrease with increasing exposure rank (table 4), the proportion of workers with a ratio less than $80 \%$ increasing from $34 \%$ in those never exposed at rank 6 or more to $53 \%$ in those currently in exposure rank 6 10. One third of the workers had measurable bronchial reactivity $\left(\mathrm{PD}_{20} \leqslant 120 \mathrm{mcmol}\right.$ ) (table 4$)$, the proportion within the main group increasing from $26 \%$ in those never exposed at rank 6 or more to $42 \%$ of those currently in exposure rank 6-10.

The stepwise linear regression analysis of the age standardised $F E V_{1} / F V C$ ratio isolated sex and current smoking as the only two significant factors. The ratio was lower in men (average $4.3 \%$ less than women) and current smokers (average $2 \cdot 4 \%$ less than current non- smokers). A $\mathrm{PD}_{20}$ of $30 \mathrm{mcmol}$ or less was significantl lo associated with ever having been exposed at rank 6 oळ higher (table 5).

\section{SKIN TESTS}

Forty per cent of the workers $(44 \%$ of the men an $\$$ $34 \%$ of the women) had a positive skin test to one of more common allergens, the commonest being pteronyssinus $(30 \%)$ (table 6$)$. A third had a positive test to one or more grain mites and there was a higho degree of concordance in the results for the five grefing mites. Of the 77 workers with a positive skin test t $\alpha \dot{B}$ pteronyssinus, $77 \%$ were positive to one or more gî? mites compared with only $14 \%$ of those with negative skin test to $D$ pteronyssinus $(\mathrm{p}<0.001)$ Positive skin tests to one or more of the other baker allergens occurred in $9 \%$, reactions to $A$ fumigatus

Table 6 Results of skin prick tests

\begin{tabular}{|c|c|c|c|c|}
\hline Positive to & $\begin{array}{l}\text { No } \\
\text { positive }\end{array}$ & $\%$ & & $\frac{D}{2}$ \\
\hline \multicolumn{5}{|l|}{$\begin{array}{l}\text { Common allergens: } \\
\text { Dermatophagoides }\end{array}$} \\
\hline pteronyssinus & 77 & 30 & & \\
\hline $\begin{array}{l}\text { Cat fur } \\
\text { B2 grass pollen }\end{array}$ & $\begin{array}{l}67 \\
48\end{array}$ & $\begin{array}{l}26 \\
18\end{array}$ & 40 & \\
\hline \multicolumn{5}{|l|}{ Grain mites: } \\
\hline Tyrophagus longior & 62 & 24 & & \\
\hline Glycyphagus destructor & 59 & 23 & & \\
\hline Acarus siro & 58 & 22 & 33 & \\
\hline Glycyphagus domesticus & 46 & 18 & & \\
\hline Tyrophagus putrescentiae & 45 & 17 & & \\
\hline Tribolium confusum (flour beetle) & 28 & 11 & & \\
\hline $\begin{array}{l}\text { Other bakery allergens: } \\
\text { Mixed flour }\end{array}$ & 14 & 5 & & \\
\hline Wheat grain & 9 & 4 & & 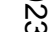 \\
\hline Mould mix & 6 & 2 & 9 & \\
\hline Bakers' yeats & 3 & 1 & & \\
\hline Aspergillus fumigatus & 1 & $<1$ & & \\
\hline Total assessed & 259 & 100 & & \\
\hline
\end{tabular}


bakers yeast, and mould mix being uncommon $(2 \%$ or less).

There was no relation between positive reactions to common allergens and exposure to dust. The highest proportion of positive responses to bakery antigen was in those with a history of exposure in rank 6 or more (table 4). A high proportion of reactions to common allergens in the intermittent exposure subset of group 7 was associated with a high proportion of positive responses to grain mites and other bakery antigens.

In the logistic regression analysis positive skin test to one or more bakery antigens was associated with atopy, a history of exposure in rank 6 or higher, and the number of years worked in the bakery (table 5).

\section{Discussion}

Total dust concentrations were measured in the production areas of this bakery and several samples exceeded the exposure limit for nuisance dust in the ingredients preparation and manufacturing areas. They were much lower in the wrapping and despatch areas. These objective measurements supported the independently derived ranking system used to classify the workforce for exposure according to job category. The measurements in cleaning and maintenance workers who were intermittently exposed showed great variability and much larger numbers of samples over longer periods would have been necessary to produce a useful profile of exposure in these subjects.

Work related symptoms were reported frequently by this workforce and sensitivity to components of flour was shown by skin prick tests in over a third of the subjects. Both were found to be more common in subjects with higher levels of bakery dust exposure. There was also evidence of exposure related respiratory effects from measurements of non-specific bronchial reactivity. By contrast, $\mathrm{FEV}_{1} / \mathrm{FVC}$ ratio was significantly related to sex and smoking but not to exposure, being lowest in men and current smokers.

Probably one or more allergens in wheat flour are responsible for the skin test responses and at least some of the respiratory effects observed in this population. Some symptoms, however, particularly nasal, are likely to be due to simple non-specific irritation. Other studies have implicated IgE in the asthma of bakers ${ }^{12} 13$ but other immunological ${ }^{5}$ and non-immunological ${ }^{14}$ responses may also operate. Further work dissecting the nature of the response is required.

This bakery has a selection policy of excluding subjects with current symptomatic asthma from employment. This selection may have been expected to reduce the numbers of atopic subjects in the study, since atopic status and bronchial hyperreactivity are associated in the general population. ${ }^{19}$ The prevalence of atopy, however, was similar to that of the general population. ${ }^{20}$ It was thought that the high prevalence of grain mite skin positivity might have resulted from cross reactivity with house dust mite but recent studies have found no such cross reactivity. ${ }^{21-23}$ In the present study a positive skin test response to grain mites was related to exposure variables whereas a response to $D$ pteronyssinus was not. This finding is being explored further. The relation of skin test responsiveness to bakery antigens with duration of exposure is consistent with the previous finding in an Australian bakery $^{23}$ and with a prospective study of skin test responses conducted over five years. ${ }^{10}$ It indicates that continued exposure results in development of sensitisation to bakery dust components.

The present study has shown that even in a modern bakery control of dust exposure presents a continuing problem. Bakery dust concentrations exceeded the exposure limit for nuisance dust at some times in some areas and sensitisation of workers had occurred as measured by skin test responses to bakery antigens. Respiratory symptoms, non-specific bronchial reactivity, and skin responses were related to exposure to bakery dust.

The help of the bakery management and staff and the Bakers' Union in the conduct of the study is gratefully acknowledged. Exposure rankings were determined by Dr P Harries and Mr B Tolley. Mrs J K Wilson and Mrs P A M Williamson helped with the air sampling. Secretarial help was provided by Miss Cathi Gray, Ms Elizabeth Bingle, Miss Carole Easton, Miss Elizabeth Corrigan, and Miss Aine Walsh.

\section{References}

1 Anonymous. Bakers' asthma. $\mathrm{Br} \mathrm{Med} J$ 1981;282:678.

2 Pritchard MG, Ryan G, Musk AW. Wheat flour sensitisation and airways disease in urban bakers. Br J Ind Med 1984;41:450-4.

3 Pritchard MG, Ryan G, Walsh BJ, Musk AW. Skin test and RAST responses to wheat and common allergens and respiratory disease in bakers. Clin Allergy 1985;15:203-10.

4 Walsh BJ, Wrigley CW, Musk AW, Baldo BA. A comparison of the binding of IgE in the sera of patients with bakers' asthma to soluble and insoluble wheat-grain proteins. $J$ Allergy Clin Immunol 1985;76:23-8.

5 Klaustermeyer WB, Bardana EJ Jr, Hale FC. Pulmonary hypersensitivity to alternaria and aspergillus in bakers' asthma. Clin Allergy 1977;7:227-33.

6 Popescu IG, Ulmeanu V, Murariu D. Atopic and non-atopic sensitivity in a large bakery. Allergol Immunopathol 1981;9: 307-12.

7 Frankland AW, Lunn JA. Asthma caused by the grain weevil. Br J Ind Med 1965;22:157-9.

8 Baur X, Fruhmann G, Haug B, Rasche B, Reiher W, Weiss W. Role of aspergillus amylase in baker's asthma. Lancet 1986; i:43.

9 Thiel H, Ulmer WT. Bakers' asthma: development and possibility for treatment. Chest 1980;78 (suppl):400-5.

10 Herxheimer $H$. The skin sensitivity to flour of bakers' apprentices. Acta Allergol 1973;28:42-9.

11 James AL, Cookson WOCM, Buters G, et al. Symptoms and 
longitudinal changes in lung function in young seasonal grain handlers. Br J Ind Med 1986;43:587-91.

12 Jarvinen KAJ, Pirila V, Bjorksten F, Keskinen H, Lentinen M, Stubb S. Unsuitability of bakery work for a person with atopy: a study of 234 bakery workers. Ann Allergy 1979;42:192-5.

13 Napolitano J, Weiss NS. Occupational asthma of bakers. Ann Allergy 1978;40:258-61.

14 Olenchock SA, Mull JC, Major PC. Extracts of airborne grain dusts activate alternative and classical complement pathways. Ann Allergy 1980;44:23-8.

15 Health and Safety Executive. Occupational exposure limits. London: HMSO, 1986. (HSE guidance notes EH40.)

16 American Thoracic Society statement. Snowbird workshop on standardization of spirometry. Am Rev Respir Dis 1979; 119:831-8.

17 Yan K, Salome C, Woolcock AJ. Rapid method for measurement of bronchial responsiveness. Thorax 1983;38:760-5.
18 Armitage P, Berry G. Statistical methods in medical research. $2 \mathrm{n} \Phi$ ed. Oxford: Blackwell, 1987.

19 Cockroft DW, Murdock KY, Berscheid BA. Relationship be tween atopy and bronchial responsiveness to histamine in $\$$ random population. Ann Allergy 1984;53:26-9.

20 Witt C, Stuckey MS, Woolcock AJ, Dawkins RL. Positive allerg prick tests associated with bronchial histamine responsiveness in an unselected population. J Allergy Clin Immunol 198 77:698-702.

21 Korsgaard J, Dahl R, Iversen M, Hallas T. Storage mites as a cause of bronchial asthma in Denmark. Allergol Immunopath 1985;13:143-9.

22 Georges P, Delvine A, de Montis G. Rast et A C Carien: desdenrées entreposées. Allergie Immunol 1987;19:393-7.

23 Van Hage-Hamsten M, Johansson SGO, Johansson E, Wiren $A \vec{D}$ Lack of allergenic cross-reactivity between storage mites and dermatophadoides pteronyssinus. Clin Allergy 1987;17:23-31 $\vec{\omega}$

\section{Vancouver style}

All manuscripts submitted to the $B r J$ Ind Med should conform to the uniform requirements for manuscripts submitted to biomedical journals (known as the Vancouver style).

The $\mathrm{Br} J$ Ind Med together with many other international biomedical journals, has agreed to accept articles prepared in accordance with the Vancouver style. The style (described in full in Br Med J, 24 February 1979, p 532) is intended to standardise requirements for authors.

References should be numbered consecutively in the order in which they are first mentioned in the text by Arabic numerals above the line on each occasion the reference is cited (Manson ${ }^{1}$ confirmed other reports ${ }^{2-5} \ldots$..). In future references to papers submitted to the $B r J$ Ind Med should include: the names of all authors if there are six or less or, if there are more, the first three followed by $e t$ al; the title of journal articles or book chapters; the titles of journals abbreviatedo according to the style of Index Medicus; and the first and final page numbers of the article of chapter.

Examples of common forms of references are:

1 International Steering Committee of Medical Editors. Uniform requirements for manuscripts submitted to biomedical journals. Br Med J 1979;1:532-5.

2 Soter NA, Wasserman SI, Austen KF. Cold urticaria: release into the circulation of histamine and eosino-phil chemotactic factor of anaphylaxis during cold challenge. $N$ Engl J Med 1976;294:687-90.

3 Weinstein L, Swartz MN. Pathogenic properties of invading micro-organisms. In: Sodeman WA Jr, Sodeman WA, eds. Pathologic physiology: mechanisms of disease. Philadelphia: W B Saunders, 1974:457-72. 